\title{
CHRISTIAN JOERGES
}

\section{A NEW ALLIANCE OF DE-LEGALISATION AND LEGAL FORMALISM? REFLECTIONS ON RESPONSES TO THE SOCIAL DEFICIT OF THE EUROPEAN INTEGRATION PROJECT ${ }^{\star}$}

\begin{abstract}
This paper will cover a wide range of issues. It will start with a reconstruction of the European Community's 'social deficit', arguing that a credible response to this deficit would be a pre-condition for the democratic legitimacy of the deepened integration project. Such a response can be developed in a re-conceptualisation of European law as a new type of supranational/trans-statal conflict of laws - this is the thesis defended in the second section. This vision is contrasted in the third section, first with the steps towards Social Europe envisaged in the Draft Constitutional Treaty, and then with the messages of the recent judgments of the European Court of Justice (ECJ) in Viking and Laval. It goes without saying that the theoretical premises of the argument, let alone its many interdisciplinary dimensions and empirical background, can often only be signalled, but not developed systematically.
\end{abstract}

KEY WORDS: conflict of laws, ordo-liberalism, 'Social Europe', social deficit, socio-economic division, unity/diversity

\section{European Integration and Democracy: A Legacy of Unresolved TENSIONS}

The project of European integration was launched not as an experiment in supranational democracy, but under the impression of the Second World War and its devastating effects on the European economies. It was meant to ensure lasting peace among former enemies, and it had as its design an integration strategy which would mitigate between the very different objectives and anxieties of

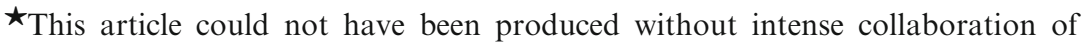
Florian Roedl, Ph.D. (EUI Florence).
} 
Germany on the one hand, and the allied victors on the other. ${ }^{1}$ This was accomplished through a primarily economic and technocratic integration strategy. This was by no means a surprising choice. With hindsight, however, the implications of this choice, which were hardly foreseeable and certainly not a salient issue half a century ago, become apparent. This is true for both the queries on which our analysis will focus.

The first may be called a 'normative fact', namely, the exclusion of the 'social' sphere from the integrationist objectives which Fritz Scharpf has famously characterised as the decoupling of the social sphere from the economic sphere. ${ }^{2}$ But why should this decoupling be problematical? The importance of this second query depends upon two further assumptions. One concerns democratic theory: the exclusion of the 'social' sphere from the integration project is a potential failure of constitutional significance only for those who assume that the citizens of constitutional democracies are entitled to vote in favour of welfare policies. This is by no means a trivial premise, not even at national level. ${ }^{3}$ The second premise concerns the integration process. Only in the course of its deepening and growing

\footnotetext{
${ }^{1}$ Students of European law tend to focus their analyses too much on the history of 'institutionalised Europe' rather than on the diverse histories of the Member States and their complex relations; J.H.H. Weiler's dichotomy between 'supranational law' and 'political intergovernmentalism' reflects this perspective (see, also, infra n. 14).

${ }^{2}$ F.W. Scharpf, "The European Social Model: Coping with the Challenges of Diversity", Journal of Common Market Studies 40 (2002), 645-670. It deserves to be stressed that the founding fathers of ordo-liberalism to whom we owe the theory of the economic constitution have insisted on the interdependence of both spheres (the Interdependenz der Ordnungen; see, famously, W. Eucken, Grundzüge der Wirtschaftspolitik (Tübingen: Mohr/Siebeck, 1952), 6th ed. 1990, 180 et seq.; out of the rich literature on the interdependence theorem, see, for an extremely subtle reconstruction, M. Wegmann, Früher Neoliberalismus und europäische Integration: Interdependenz der nationalen, supranationalen und internationalen Ordnung von Wirtschaft und Gesellschaft (1932-1965) (Baden-Baden: Nomos, 2002), in particular at 369 et seq.

${ }^{3}$ Friedrich August von Hayek was the most outspoken critic of this thesis; the turn to welfare policies means taking The Road to Serfdom (London: Routledge, 1944). A legendary debate in the young German Federal Republic between Wolfgang Abendroth and Ernst Forsthoff concerned precisely that problématique (see A. Fischer-Lescano and O. Eberl, "Der Kampf um ein soziales und demokratisches Recht. Zum 100. Geburtstag von Wolfgang Abendroth" (2006) Blätter für deutsche und internationale Politik 51, 577-585) and these debates are going on until today (see C. Harvey, ed. Special Issue on "Social Democracy", Canadian Journal of Law and Jurisprudence on Social Democracy 17 (2004)).
} 
impact on the 'economy and society' will a response to the 'social deficit' become a political must. ${ }^{4}$

\section{Europe's Equilibrium in the Formative Period of the Integration Process}

Legal integration theory is an effort to provide a contextually (historically, socially and politically) 'adequate' legal conceptualisation of the state of the European Community (now Union). Two such efforts to capture the 'nature of the beast' in its formative period stand out and remain important: ${ }^{5}$ Germany's ordo-liberalism and Joseph Weiler's theory of supranationalism.

Ordo-liberalism is an important theoretical tradition in Germany, and a powerful contributor to German ideational politics. The ordoliberal school ${ }^{6}$ reconstructed the legal essence of the European project as an 'economic constitution' which was not in need of anything like democratic legitimacy. The freedoms guaranteed in the EEC Treaty, the opening up of national economies, and anti-discrimination rules and the commitment to a system of undistorted competition were interpreted as a 'decision' that supported an economic constitution, and which also matched the ordo-liberal conceptions of the framework conditions for a market economic system. The fact that Europe had started out on its integrationist path as a mere economic community lent plausibility to ordo-liberal arguments - and even required them: in the ordo-liberal account, the Community acquired a legitimacy of its own by interpreting its pertinent provisions as prescribing a law-based order committed to guaranteeing economic freedoms and protecting competition by supranational institutions. This legitimacy was independent of the state's democratic constitutional institutions. By the same token, it imposed limits upon the Community: thus,

\footnotetext{
${ }^{4}$ For a brilliant recent analysis of this interdependence see J.P. McCormick, Weber, Habermas, and Transformations of the European State. Constitutional, Social, and Supranational Democracy (Cambridge, Cambridge UP, 2007).

5 Viking and Laval can even be read as a revival of ordo-liberal ideas; see the third section in this paper, infra.

${ }^{6}$ European integration was, in its early years, by no means an uncontested project in the ordo-liberal school (see M. Wegmann, supra n. 3). Her analyses fit well the enquiry into the politics of competition policy by Y. Karagiannis, "Preference Heterogeneity and Equilibrium Institutions: The Case of European Competition Policy", unpublished doctoral thesis, EUI Florence (2007), ch. 7.
} 
discretionary economic policies seemed illegitimate and unlawful. ${ }^{7}$ The ordo-liberal European polity has a twofold structure: at supranational level, it is committed to economic rationality and a system of undistorted competition, while, at national level, re-distributive (social) policies may be pursued and developed further.

'Integration through law' is the legal paradigm commonly associated with the formative era of the European Community outside the German borders. ${ }^{8}$ It is not by chance that generations of scholars have built upon it or tried to decipher its sociological basis. ${ }^{9}$ The strength of the paradigm may well rest (in part!) on assumptions that become apparent only when we look at social and economic policy through its lens. Then we become aware of the Wahlverwandtschaft with German ordo-liberalism in that only the European marketbuilding project was juridified through supranational law, whereas social policy at European level could, at best, be said to have been handled through intergovernmental bargaining processes.

Fritz Scharpf's decoupling thesis is, at least on the surface, not meant as a contribution to the debates on the constitutionalisation of Europe. It does, however, build upon sociological assumptions with constitutional implications, and this holds true, in particular, for the argument that the social integration of capitalist societies requires equilibrium between social and economic rationality. This is, of course, again a primarily empirical issue, but it is one with obvious implications for the legitimacy of the polity under scrutiny. ${ }^{10}$ Since we can assume that 'welfarism' - notwithstanding its diverse modes is a common European heritage, ${ }^{11}$ it becomes imperative for the integration project to address the 'social' sphere. Interestingly enough, German ordo-liberalism used to be well aware of this problématique - its early proponents conceptualised it as the

\footnotetext{
${ }^{7}$ Significant, here, is A. Müller-Armack, "Die Wirtschaftsordnung des Gemeinsamen Marktes", ibid., Wirtschaftsordnung und Wirtschaftspolitik (Freiburg: Rombach, 1966), 401 et seq.

8 See J.H.H. Weiler, "The Community System: the Dual Character of Supranationalism", in Yearbook of European Law 1 (1981), 257-306.

9 Most recently, A. Vauchet, "A Europe of Norms. A Political Sociology of a "Community of Law", 2007 (manuscript on file with author).

${ }^{10}$ See the classical studies by J. Habermas: Legitimationsprobleme im Spätkapitalismus (Frankfurt a.M.: Suhrkamp, 1973); Zur Rekonstruktion des Historischen Materialismus (Frankfurt a.M.: Suhrkamp, 1976), and J.P. McCormick, supra n. 5, 176 et. seq.

11 See T. Judt, Postwar. A History of Europe Since 1945 (New York: Penguin, 2005) at 777 et seq.
} 
interdependence of societal and economic 'orders' (Ordnungen/ Verfassungen $^{12}$ ).

To summarise: Europe was constituted as a dual polity. Its 'economic constitution' was non-political in the sense that it was not subject to political interventions. This was its constitutional-supranational raison d'être. Social policy was treated as a categoricallydistinct subject. It belonged to the domain of political legislation, and, as such, had to remain national. The social embeddedness of the market could, and, indeed, should, be accomplished by the Member States in differentiated ways - and, for a decade or so, the balance seemed stable. ${ }^{13}$

\section{The Completion of the Internal Market, the Erosion of the Economic Constitution, and the Advent of Social Europe}

The original equilibrium was not, however, to remain steady. One important reason for its instability is the progress of the integration project. This is not really paradoxical, not even surprising in the light of the considerations in the previous section.

The Delors Commission's 1985 White Paper on Completion of the Internal Market ${ }^{14}$ is widely perceived as a turning point and a breakthrough in the integration process. Jacques Delors' initiative promised to overcome a long phase of stagnation; the means to this end was the strengthening of Europe's competitiveness. Economic rationality, rather than 'law', was - from that point on - to be understood as Europe's orienting maxim, its first commitment and its

12 Verfassung in German has a double meaning. It can be a legal constitution and a social structure or pattern. The notion of Ordnung (order), too, comprises this twofold meaning. This clarification is necessary to convey our idea of a constitutionalisation of the economy, of other societal spheres or parts of the legal system. Such constitutionalisation can either claim the dignity of constitutional law (e.g., supremacy within the legal system) or be an integral part of the constitutional order. In this latter sense, Jürgen Habermas talks of the co-originality of private and public law; see his Faktizität und Geltung (Frankfurt a.M., Suhrkamp, 1992), 112 et seq.

13 This all fits well into the analysis of "the national configuration of the state in the Golden Age", by St. Leibfried and M. Zürn, "Reconfiguring the National Constellation", in St. Leibfried and Michael Zürn, eds, Transformation of the State (Cambridge: Cambridge UP, 2005), 93-117. It also seems worth noting that the ordo-liberal construct has structural affinities, or is at least compatible, with J.H.H. Weiler's analysis of the co-existence of and interdependence between legal supranationalism and political intergovernmentalism in the EEC (see supra n. 8).

${ }^{14}$ EC Commission, "Commission White Paper to the European Council on Completion of the Internal Market”, COM (85) 310 final of 14 June 1985. 
regulative idea. In this sense, it seems justified to characterise Delors' programme as a deliberate move towards an institutionalisation of economic rationality. This seems even more plausible when we consider the two complementary institutional innovations accomplished through, and subsequent to, the Maastricht Treaty, namely, Monetary Union and the Stability Pact. Europe looked like a marketembedded polity governed by an economic constitution, rather than by political rule.

This characterisation, however, soon proved to be too simplistic by far. ${ }^{15}$ What had started out as an effort to strengthen Europe's competitiveness and to accomplish this objective through new (deregulatory) strategies, soon led to the entanglement of the EU in ever more policy fields and the development of sophisticated regulatory machinery. It was, in particular, the concern of European legislation and the Commission with 'social regulation' (the health and safety of consumers and workers, and environmental protection) that served as irrefutable proof of this. The weight and dynamics of these policy fields had been thoroughly underestimated by the proponents of the 'economic constitution'. Equally important and equally unsurprising was the fact that the integration process deepened with the completion of the Internal Market and affected ever more policy fields. This was significant not so much in terms of its factual weight but, in view of Europe's 'social deficit', in terms of the new efforts to strengthen Europe's presence in the spheres of labour and social policy.

These tendencies entered the mainstream during the preparation of the Maastricht Treaty, which was adopted in 1992. This is why this Amendment of the Treaty, officially presented as both a deepening and a consolidation of the integration project, met with fierce criticism. The most outspoken critique came not from the political left, but from the proponents of the new economic philosophy and, in particular, from Germany's ordo-liberals. ${ }^{16}$ Indeed, the Maastricht Treaty of 1992 can be read as a break with the ordo-liberal economic constitution. After the explicit recognition and strengthening of new policy competences, which was accomplished in Maastricht, it seemed simply no longer plausible to assign a constitutive function to the "system of undistorted competition' because this very 'system' had been downgraded to being

${ }^{15}$ For more details see C. Joerges, "Economic Law, the Nation-State and the Maastricht Treaty", in R. Dehousse, ed., Europe after Maastricht: an Ever Closer Union? (Munich: C.H. Beck, 1994), 29-62.

${ }^{16}$ See M. Streit and W. Mussler, "The Economic Constitution of the European Community. From 'Rome' to 'Maastricht'”, European Law Journal 1 (1995), 5-30. 
one among many others. In addition, the expansion of competences in labour law by the Social Protocol and Agreement on Social Policy of the Treaty blurred the formerly clear lines between Europe's (apolitical) economic constitution and the political responsibility that Member States had for social and labour policies.

Until today, a consensus on the interpretation of this new constellation did not emerge. Was this a result of contingent events and decisions? Was there a deeper 'logic' at work? Back in 1944, Karl Polanyi, in his seminal Great Transformation, had argued that markets will always be 'socially embedded'. ${ }^{17} \mathrm{He}$ had not spelled out the political and normative implications of his sociological observations, but the European experience seems, in principle, reconcilable with his messages. Once it became apparent that markets could not be understood simply as being mechanisms that functioned perfectly and automatically to adjust supply and demand, the 'critical question' was:

[n]o longer the quantitative issue of how much state or how much market, but rather the qualitative issue of how and for what ends should markets and states be combined and what are the structures and practices in civil society that will sustain a productive synergy of states and markets. ${ }^{18}$

It is far beyond my competence to evaluate, let alone to substantiate, such suggestions. All I wish to submit is that the 'social embeddedness' thesis can help us to understand why Europe has developed an ever more sophisticated regulatory machinery entrusted with the management of the internal market - and why the social deficit of the European construction has become a prominent part of the European agenda.

\section{Conflict of Laws as Constitutional Form}

To rephrase the concluding remark of the previous section: lawyers are ill-equipped to decipher the historical, political and sociological determinants of the developments of law. Their vocation may

17 K. Polanyi, The Great Transformation: The Political and Economic Origins of Our Time (1944) (Boston: Bacon Press, 1992), at 45-58, and 71-80.

18 See F. Block, "Towards a New Understanding of Economic Modernity", in C. Joerges, B. Stråth and P. Wagner, eds, The Economy as a Polity. The Political Construction of Modern Capitalism - An Interdisciplinary Perspective (London: UCL Press, 2005), 3; and most recently J. Beckert, "The Great Transformation of Embeddedness: Karl Polanyi and the New Economic Sociology", MPIfG Discussion Paper 07/1. 
however, be to offer legal conceptualisations which are compatible with what we know about the law's context - and, at the same time, seek to explain whether, or under what conditions, a deliberate adaptation to these contexts would 'deserve recognition'.

This is by no means a revolutionary suggestion, but is rather a continuous challenge for legal scholarship, in particular for students of European law who are confronted with a moving target and thus have to conceptualise a 'Wandelverfassung'. ${ }^{19}$ The idea of a new type of conflict of laws as Europe's proper constitutional form, for which this section will argue, should be read in this light. Our suggestion is less idiosyncratic in substance than the terminology it uses may appear to propose; indeed, the core argument upon which it rests is in fact quite simple. Back in 1997, Jürgen Neyer and I submitted it under the heading of 'deliberative' (as opposed to 'orthodox') supranationalism: ${ }^{20}$

The legitimacy of governance within constitutional states is flawed in so far as it remains inevitably one-sided and parochial or selfish. The taming of the nation-state through democratic constitutions has its limits. [If and, indeed, because] democracies pre-suppose and represent collective identities, they have very few mechanisms [through which] to ensure that 'foreign' identities and their interests are taken into account within their decision-making processes. ${ }^{21}$

If the legitimacy of supranational institutions can be designed to cure these deficiencies - as a correction of 'nation-state failures', as it were - they may then derive their legitimacy from this compensatory function. To quote a recent restatement:

We must conceptualise supranational constitutionalism as an alternative to the model of the constitutional nation-state which respects that state's constitutional legitimacy, but, at the same time, clarifies and sanctions the commitments arising from its interdependence with equally democratically legitimised states and with the supranational prerogatives that an institutionalisation of this interdependence requires. $^{22}$

${ }^{19}$ H.P. Ipsen, "Die Verfassungsrolle des Europäischen Gerichtshofs für die Integration", in J. Schwarze, ed., Der Europäische Gerichtshof als Verfassungsgericht und Rechtsschutzinstanz (Baden-Baden: Nomos, 1982), 29 et seq.

20 C. Joerges and J. Neyer, "From Intergovernmental Bargaining to Deliberative Political Processes", European Law Journal 3 (1997), 273-299.

21 Ibid., at 293.

${ }^{22}$ C. Joerges “'Deliberative Political Processes' Revisited: What have we learnt about the Legitimacy of Supranational Decision-Making", Journal of Common Market Studies 44 (2006), 779-802, at 790. 
This, of course, is not the way in which the supranational validity of European law was originally understood and justified. Fortunately enough, however, the methodologically and theoretically bold and practically successful ECJ decision in favour of a European legal constitution $^{23}$ can be rationalised in this way. The European 'federation' thus found a legal constitution that did not have to aim at Europe's becoming a state, but was able to derive its legitimacy from the fact that it compensates for the democratic deficits of the nation states. This is precisely the point of deliberative supranationalism. Existing European law had, we argued, validated principles and rules that meet with and deserve supranational recognition because they constitute a palpable community project: Community members cannot implement their interests or laws without restraint, but are obliged to respect the European freedoms; they are not allowed to discriminate and can pursue only legitimate regulatory policies which have been blessed by the Community; they must, in relation to the objectives that they wish to pursue through regulation, harmonise with each other, and they must shape their national systems in the most community-friendly way possible.

Why should this type of law be called a new type of conflict of laws? This notion reminds us of Europe's internal diversity, that it represents the effort to live with diversity rather than to strive for uniformity, the fact that diversity is a cause of conflict of interests both, horizontally, among Member States and societal actors and, vertically, between the different levels of governance and the institutional actors representing them. ${ }^{24}$ On the other hand, conflict of laws has traditionally - in all its sub-disciplines: private international law, international administrative law, international labour law, etc., refused to apply foreign 'public' law; each state determined the international scope of its own public law unilaterally. Traditional conflict of laws is, therefore, a paradigm example of what Michael Zürn characterises as 'methodological nationalism'. 25 The 'new' European conflict of laws has, of course, to overcome this hostility, and the principles just cited do exactly that: they guide the search for responses to conflicting claims where no higher substantive law is

${ }^{23}$ Case 26/62, [1963] ECR 1 - Van Gend en Loos v. Nederlandse Administratie der Belastingen.

${ }^{24}$ R. Mayntz, "The Architecture of Multi-level Governance of Economic Sectors", MPIfG Discussion Paper 07/13, at 22-24.

25 M. Zürn, "The State in the Post-National Constellation - Societal Denationalisation and Multi-Level Governance", Oslo: ARENA Working Paper No. 35/1999. 
readily available. To give voice to foreign' concerns means, in the EU, first of all, that Member States mutually 'recognise' their laws (that they are prepared to 'apply' foreign law), that they tolerate legal differences and refrain from insisting on their own lex fori and domestic interests. This European law of conflict of laws is 'deliberative' in that it does not content itself with appealing to the supremacy of European law; it is 'European' because it seeks to identify principles and rules that make different laws within the EU compatible with one another. ${ }^{26}$ The conflict of laws approach envisages a horizontal constitutionalism for the EU. It distances itself from both the orthodoxy of conflict of laws and from orthodox supranationalism, which promotes top-down solutions to Europe's diversity. It seeks to accomplish what the Draft Constitutional Treaty had called the 'motto of the Union', ${ }^{27}$ namely, the vision of 'unity in diversity'. Is this a new perspective for solving Europe's social deficit?

\section{Soft and Hard Responses to the Quest for Social Europe}

In a recent essay dealing with state of the European Union after the signing of the Reform Treaty, Jürgen Habermas took issue with the tendency of Germany's Social Democrats to respond to the risks of economic globalisation by using the means of the national welfare state. Would it not be preferable, he asked, to search for co-ordinated responses within the whole European economic space? ${ }^{28}$ His question

${ }^{26}$ I refrain here from explaining two further implications in depth, but I shall mention them. One is methodological: European conflict of laws requires a proceduralisation of the category of law, which has to be understood as a 'law of lawmaking' (see F.I. Michelman, Brennan and Democracy, New Jersey: Princeton UP, 1999, 34), a Rechtfertigungs-Recht (R. Wiethölter, "Just-ifications of a Law of Society", in O. Perez and G. Teubner, eds, Paradoxes and Inconsistencies in the Law (Oxford: Hart, 2005), 65-77). The second concerns the need for a 'second order of conflict of laws'. This need stems from the 'turn to governance' that we witness not just at the European level but also with nation states. Just as nation states have long had to learn to deal with complex conflict situations, to integrate expertise in legal decision-making and to co-operate with non-governmental actors, the EU had to build up governance arrangements which complement its primary and secondary law. 'Second order conflict of laws' seeks to constitutionalise this sphere, primarily through a proceduralisation of law; for more detail, see C. Joerges, "Integration through De-legalisation?", European Law Review 33 (2008), 291-312.

27 Article I-8 of the Draft Treaty on a Constitution for Europe, OJ C310/1, 16/12/ 2004.

28 "Erste Hilfe für Europa”, DIE ZEIT no.49/2007. 
implicitly acknowledges the importance of Europe's social deficit, but which answers are available? We are currently witnessing two seemingly contradictory, albeit complementary responses, namely, the resort to soft modes of governance on the one hand, and the return to orthodox supranationalism on the other.

\section{Social Rights and Soft Co-ordination}

The first-named alternative was the option pursued by the Draft Constitutional Treaty ${ }^{29}$ and a great number of its supporters. 'Social Europe' was to rest, in particular, on three corner stones: the commitment to a 'competitive social market economy', ${ }^{30}$ the recognition of 'social rights', ${ }^{31}$ and 'soft law' techniques for the co-ordination of social policies. ${ }^{32}$ Joschka Fischer and Domenique de Villepin, to whom we owe the assignment of constitutional dignity to the concept of the 'social market economy', were giving a political signal, but they were hardly aware of the interdependence of the economic and the social constitution in the theory of the 'soziale Marktwirtschaft'. This legacy would have required what was not yet an imperative in the formative era of the European Economic Community, namely, a compensation for the decoupling of both spheres in the European Treaty. ${ }^{33}$ The new social rights and the new co-ordination competences thus had to carry the hopes of being a cure, ${ }^{34}$ but this hope was never founded on solid ground. ${ }^{35}$ Undoubtedly, the social rights agenda will survive both the Draft Constitutional Treaty and the Lisbon Treaty in some form, as will the Open Method of Co-ordination; however, in the present context, we cannot and indeed need not examine the intrinsic merits and failures of these specific options,

29 The Lisbon Treaty as signed on 13 December 2007 does not advance this agenda.

30 Article 3 (3), DCT

31 See Title IV DCT.

32 See, especially, Article I-14 (4) DCT on the assignment of a competence 'to promote and co-ordinate the economic and employment policies of the Member States' has been repealed. Article I-11(3) as amended on 22 June 2004.

${ }^{33}$ See, in more detail, C. Joerges and F. Rödl, "The "Social Market Economy" as Europe's Social Model?", in L. Magnusson and B. Stråth, eds, A European Social Citizenship? Pre-conditions for Future Policies in Historical Light (Brussels: Lang, 2005) 125-158.

34 See the contributions to G. de Búrca and B. de Witte, eds, Social Rights in Europe (Oxford: Hart, 2005) and G. de Búrca and J. Scott, eds, Law and New Governance in the EU and the US (Oxford: Hart, 2006).

35 See C. Joerges and F. Rödl, supra n. 33. 
because the recent jurisprudence of the ECJ has served to re-configure the agenda. After Viking and Laval, one will have to ask what the objective of soft methods of co-ordination can be in the confrontation with the hard law of negative integration.

\section{The ECJ Judgments in Viking and Laval}

The two cases have attracted wide attention over the last years. The conflicts that they deal with are directly related to the new socio-economic diversity in the Union subsequent to its Eastern Enlargement. In both cases, 'old' (high wage) Member States defend the principle that their wage level must not be eroded by low wage offers from the new Member States, and invoke the economic freedoms guaranteed by the Treaty that they had made strategic use of in the past, namely in order to operate at home at the wage levels of their eastern neighbours. 'It is a bracing reminder to EU lawyers of the power of political and economic context to influence legal doctrine', observes Brian Bercusson, ${ }^{36}$ 'that the new Member States making submissions were unanimous on one side of the arguments on issues of fundamental legal doctrine (horizontal direct effect, discrimination, proportionality) and the old Member States virtually unanimous on the other'.

\section{Viking}

The plaintiffs in the Viking case ${ }^{37}$ were a Finnish shipping company (Viking) and their Estonian subsidiary. Viking was a large ferry operator, one of which was the ferry Rosella, which was registered in Finland and had a predominantly Finnish crew. A collective agreement negotiated by the Finnish Seamen's Union provided that the wages and conditions of employment were to be at the Finnish level. The Rosella was running at a loss and Viking decided to re-flag the ferry in Estonia, with the Finnish crew to be replaced by less costly Estonian seamen. Both the Finnish and the Estonian Union were affiliates to an international federation, the International Transport Workers' Federation (ITF), whose prime policy targets included that of 'flags of convenience'. It is the ITF's objective to achieve collective

\footnotetext{
36 "The Trade Union Movement and the European Union: Judgment Day", European Law Journal 13 (2007), 279-308.

37 Case C-438/05, Viking Line Abp OU Viking Line Eesti v The International Transport Workers' Federation, The Finnish Seamen's Union. For a detailed analysis, see B. Bercusson “'Six Scenarios in Search of an Author...' Or Solutions for the European Court in the Cases of Laval and Viking" (Typescript, London, 2007), on file with author.
} 
agreements under the law of the place where the beneficial ownership and control of the vessel lie, and to defend in this way seafarers against low wage strategies of employers such as Viking, who seek to replace their seafarers with a workforce from low-wage countries. Following this policy, ITF urged its member unions not to enter into negotiations regarding a new agreement with Viking. As the ECJ noted, ${ }^{38}$ such a policy would, if effective, render re-flagging pointless, and this was the reason why Viking brought an action first in Helsinki and then before the Court of Justice of England and Wales, arguing inter alia that the threatened collective action was incompatible with Viking's freedom of establishment as guaranteed by Article 43.

Two of the ECJ's pronouncements are of particular interest here. The first is that Article 43 'applies' to collective action initiated in order to induce an undertaking to enter into a collective agreement. This 'application' of Article 43 is, however, tempered by the right to strike, which 'must be recognised as a fundamental right which forms an integral part of the general principles of Community law', ${ }^{39}$ and '[i]n that regard, the Court has already held that the protection of fundamental rights is a legitimate interest which, in principle, justifies a restriction of the obligations' to respect the economic freedoms. ${ }^{40}$ The Court appears just to be making a small move here, the effect of which is simply to bring the framework which Community law has developed in the assessment of the legitimacy of restrictions imposed by national law to bear. However, in the Viking case, this move concerned an area of the law in which the Community has very limited competences, as Article 137(5) explicitly provides. Can the recognition of the right to strike imply the competence to interfere with the social functions assigned to this right within the national legal systems and their 'Arbeits- und Sozialverfassungen'? This is what the Court implicitly seems to suggest in the next paragraph, where it states that the exercise of fundamental rights 'must be reconciled with requirements related to rights protected under the Treaty and in accordance with the principle of proportionality'. ${ }^{41}$

This coupling of the European economic freedoms with national labour law is completed by the second step that the Court takes when it equates the obstacles to the freedom of movement created by state barriers with 'obstacles resulting from the exercise, by associations or

\footnotetext{
38 Case C-438/05, para.18.

39 Ibid., para. 44.

40 Ibid., para. 45.

41 Ibid., para. 46.
} 
organisations not governed by public law, of their legal autonomy'. ${ }^{42}$ Indeed, the Court then goes on to underline that 'the activities of the Community are to include "a policy in the social sphere". ${ }^{43}$ This 'social purpose' would legitimate collective action aimed at 'protecting the jobs and conditions of employment', provided they responded to a 'serious threat' to the union members and 'do not go beyond what is necessary to attain that objective' ${ }^{44}$

The Court leaves this evaluation to the national court. The guidance it provides remains limited - and somewhat indeterminate. Action against the registering of a vessel in another Member State 'cannot be objectively justified'; nevertheless, a protective policy remains justifiable. However, solidarity action undertaken regardless of the degree of protection available in the state of reflagging is going too far. ${ }^{45}$ In Viking, the Court took bold steps toward the establishment of a Community framework for the supervision of industrial action, but then showed judicial self-restraint when it came to the exercise of that supervision. In Laval, such prudence is no longer visible.

\section{Laval}

The plaintiff in the Laval case ${ }^{46}$ was a company incorporated under Latvian law, whose registered office was in Riga. Laval's Swedish subsidiary (Bygg AB) had won the tender for a school building on the outskirts of Stockholm and, in obtaining the tender, Bygg AB had profited from its ability to post workers from Latvia to Sweden, and the considerably lower wage level in Latvia. In May 2004, Laval posted several dozen of its workers to work on the Swedish building sites.

Sweden had implemented the 1996 posted workers' directive ${ }^{47}$ in 1999, but its implementing legislation did not introduce a system for

42 Ibid., para. 57. Space constraints here do not permit a discussion of the case law the Court invokes, so it must suffice to recall the sensitivity with which Community law and policy proceeded in the cases of obstacles to free movement created by 'private' standardisation. See H. Schepel, The Constitution of Private Governance. Product Standards in the Regulation of Integrating Markets (Oxford: Hart, 2005) 37 et seq.

43 Case C-438/05, para. 78.

44 Ibid., para. 81, 84.

45 Ibid., para. 88, 89.

46 Case C-341/05, Laval un Partneri Ltd v Svenska Byggnadsarbetareforbundet, Svenska Byggnadsarbetareforbundet, Avdelning 1, Svenska Elektrikerforbundet.

47 Directive 96/71/EC concerning the posting of workers in the framework of the provision of services. OJ 1996, L18/1. 
declaring collective agreements universally applicable as foreseen in Article 3(8) of the Directive. ${ }^{48}$ Swedish law does not require foreign undertakings to apply the pertinent local collective agreements. However, trade unions are entitled to take action in order to attain the imposition of the higher Swedish wages. The Swedish building and public works trade union and also, in support, the electricians' trade union, did this with such determination and intensity, in particular through the picketing of building sites, that Laval gave up.

The first question that the Court was required to answer concerned both European primary law, namely, the freedom to provide services (Article 49) and the prohibition of discrimination (Article 12), and secondary law, namely, the posted workers' directive just cited. The Directive does not harmonise the substantive provisions on the employment of posted workers: rather, it subjects this relationship in principle to the law of the host state (Article 50). As indicated, in its transposition of Directive 96/71, Sweden neither provided for minimum wages (which would have been compatible with Article 3(1) of the Directive, nor declared pertinent collective agreements to be universally applicable (as foreseen in Article 3(8)). Had anybody in Sweden or elsewhere in the negotiation process realised that this subsection of the Directive would require an amendment of the Swedish Constitution? Could the ECJ have placed more emphasis on the fact that, as pointed out by G.A. Mengozzi, ${ }^{49}$ Directive 96/71 did not aim to harmonise 'either the substantive rules of the Member States as regards employment law and the terms and conditions of employment relating, in particular, to rates of pay, or the right to resort to collective action'? Should the incompatibility between the modes foreseen in Directive 96/71 and the Swedish constitutional system be judged in the light of Article 137(5) EC, which expressly reserves to the powers of the Member States the regulation of 'pay, the right of association, the right to strike or the right to impose lockouts'? The Court ruled otherwise: Swedish law must not empower unions to insist on collective agreements,

\footnotetext{
48 This Article provides in its first sub-section: 'Collective agreements or arbitration awards which have been declared universally applicable' means collective agreements or arbitration awards which must be observed by all undertakings in the geographical area and in the profession or industry concerned; see Case C-341/05, paras. 65,84 .
}

49 See para. 58 of his opinion in Case C-341/05. 
certain terms of which depart from [European] legislative provisions and establish more favourable terms and conditions of employment as regards the matters referred to in Article 3(1), first sub-paragraph, (a) to (g) of Directive 96/71 and others relate to matters not referred to in that provision. ${ }^{50}$

Hidden in this statement is a strong supremacy claim: Directive 96/71 is certainly an important piece of European labour law. It is not, however, an element of some comprehensive system of labour and social law, whereas the Swedish guarantee of the right to take collective action in its Constitution needs to be understood as an integral part of the Swedish social model. ${ }^{51}$ Is the EC entitled to insist that Sweden re-define the role of the trade unions and the competences of the state which form part of the Swedish Constitution because of one sub-section of a European directive?

We will return to this conflict-of-laws' issue. In the present case, it is only of practical importance in the context of Article 49, as alluded to in the first part of the passage cited: does European law affect the right to industrial action as Sweden grants it to trade unions? As in Viking, the ECJ underlined that 'the right to take collective action must ... be recognised as a fundamental right which forms an integral part of the general principles of Community law' and that their protection by a Member State is understood as a 'legitimate interest' in Community law. ${ }^{52}$ This confirmation, however, is followed by a move which fundamentally reconfigures the balance between economic freedoms and social rights at national level:

It should be noted that ... Article 49 EC became directly applicable in the legal orders of the Member States on expiry of the transitional period and confers on individuals' rights which are enforceable by them and which the national courts must protect. $^{53}$

Somewhat ironically, the disempowerment of Swedish trade unions which this insertion of a new fundamental (economic) right into the Swedish constitutional order implies is also presented as reflecting a European achievement in the cure of its social deficit:

...[T]he Community has ... not only an economic but also a social purpose, the rights under the provisions of the EC Treaty on the free movement of goods, persons, services and capital must be balanced against the objectives pursued by social policy, which include, as is clear from the first paragraph of Article $136 \mathrm{EC}$, inter alia,

\footnotetext{
50 Ibid., 99.

51 See Case C-341/05, paras. 10, 92.

52 Case C-341/05, paras. 91, 93 \& 103.

53 Ibid., para. 97.
} 
improved living and working conditions, so as to make possible their harmonisation while improvement is being maintained, proper social protection and dialogue between management and labour. ${ }^{54}$

This amounts to nothing less than a re-writing of the Swedish social model, not in the name of European economic constitution such a move would be difficult to understand in the light of the degrading of 'the system of undistorted competition' from an objective to a mere instrument by the Lisbon Treaty - but in the name of an incomplete European social constitution and the reservation of Member State competences by Article 137(5). ${ }^{55}$

\section{True Conflicts and the Judicial Function}

The references to conflict of law in the second section (see above) did not mention a query with traditional conflict of laws, which was raised by the American conflict-of-laws scholar Brainerd Currie back in the 1960s. This query concerned the judicial function in interstate constellations:

[C]hoice between the competing interests of co-ordinate states is a political function of a high order, which ought not, in a democracy, to be committed to the judiciary: ...the court is not equipped to perform such a function; and the Constitution specifically confers that function upon Congress. ${ }^{56}$

Currie was writing for the federal system of the US, and thus there are important differences to consider before one brings his query to the EU. ${ }^{57}$ One difference, or European peculiarity, was underlined at the beginning, namely, the decoupling of the social from the economic constitution and the difficulties militating against the

\footnotetext{
54 Ibid., para. 105.

55 The second question the Court was asked concerned the importance of collective agreements signed by Laval in Latvia. The Court here was not considering that such agreement should be recognised as equivalent to those of Sweden - such a suggestion would be plainly incompatible with the posted workers' directive. Instead, it held that it was discriminatory to treat Laval as an undertaken which had not concluded any collective agreement (para. 116).

56 B. Currie, "The Constitution and the Choice of Governmental Law: Interests and the Judicial Function", (1958), in Selected Essays (Durham NC: Duke UP, 1963), 188-282, at 272.

${ }^{57}$ F. Rödl, "Weltbürgerliches Kollisionsrecht” Ph.D. Thesis EUI 2008, Part 2, A II.2, suggests that Currie's objection against a weighing of governmental interests in cases of true conflicts is to be understood in the light of the presence of a constitutional court in the American federal system. My own evaluation of the different constitutional constellations goes in the opposite direction.
} 
establishment of a single European Sozialstaat. The ECJ's argument implies that European economic freedoms, tamed only by an unspecified 'social dimension' of the Union, trump the Arbeits- and Sozialverfassung of a Member State, even though the Treaty expressly restricts Community competences in this field. In view of the obstacles to the establishment of a comprehensive European welfare state, the respect of the common European legacy of Sozialstaatlichkeit seems to require the acceptance of European diversity and an exercise of judicial self-restraint where European economic freedoms come into conflict with national welfare traditions. The ECJ, however, is not a constitutional court with comprehensive competences - it is not legitimated to re-organise the interdependence of Europe's social and economic constitutions, let alone to replace the variety of European social models with a uniform Hayekian Rechtsstaat. It should therefore refrain from 'weighing' the values of Sozialstaatlichkeit against the value of free market access and stick to its 'proper' function, which, we have argued, is to develop supranational law which compensates for the 'democracy failures' of nation states. National welfare traditions do not - by definition - represent such failures, and their defence does not require a suspension of the accomplishments of democratic constitutionalism. What was at issue in Viking was the post-national strategy of the trade unions, who sought to respond to the social consequences of reflagging, while in Laval what was at issue was not the soundness of the posted workers' directive, but the strategic use of wage differences within the EU. What the trade unions employed was a means to counter the increase in power accrued by the employer due to the European economic freedoms; to argue that the right to collective action to national constellations that is subject to a European freedom is not only to confirm the de facto decoupling of the social from the economic constitution, but also to subject the former de jure to the latter.

A definite evaluation of the impact of Viking and Laval is not yet possible but it is sufficiently clear, however, that this jurisprudence is a hard law step of negative integration. What about the chances for a correction of this step by the soft means of the Open Method of Co-ordination? Here it seems telling that in both of these cases the move against old labour law was initiated in high wage countries. Is it in the long-term interest of the new Member States to dismantle the welfarism of their western and northern European neighbours? What would that mean for their long-term competitive advantages and their chances for similar developments? 


\section{Open ACCess}

This article is distributed under the terms of the Creative Commons Attribution Noncommercial License which permits any noncommercial use, distribution, and reproduction in any medium, provided the original author(s) and source are credited.

CHRISTIAN JOERGES

Law Faculty

University of Bremen,

Bibliothekstraße 1, 28359, Bremen, Germany

E-mail:cjoerges@zerp.uni-bremen.de 